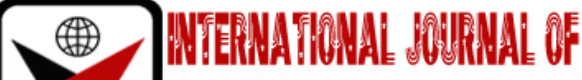

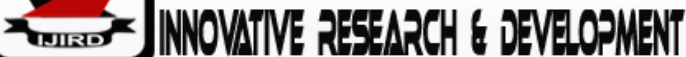

ISSN 2278-0211 (Online)

\section{Political Economy of Terrorism as Hindrance to the Implementation of Nigeria's Counter Terrorism Strategies to End Insurgency in the North East}

\author{
Simeon Oludele-Ajiboye \\ Principal Research Fellow, Institute for Peace and Conflict Resolution,Abuja-Nigeria
}

\begin{abstract}
:
The frequent terror attacks with its attendant consequences by Boko Haram Terror Group in Nigeria, has become almost daily occurrence which necessitated Nigerian Government to develop counter-terrorism measures in addressing insurgency in the country. The counter-terrorism mechanism can only succeed when politics and economic considerations are not allowed to influence the counter measures to fight terrorism in the country. The interplay of politics and economy with other factors are found capable of hindering the success of counter-terrorism strategies put in place to defeat terrorism in Nigeria.
\end{abstract}

Keywords:Political, economy, terrorism, counter-terrorism, insurgency

\section{Introduction}

Before September 11, 2001, terror attack on the United States of America (USA), terrorism was receiving low attention or at best treated as mere group agitations. The September 11 attacks compelled policy makers, international organizations, regional groupings to start mobilizing resources to counter terrorism worldwide. New laws and measures to combat terrorism began to emerge all over the world. Nigeria was not left out in developing measures to address the problem of terrorism in Nigeria. Nigeria began to experience act terrorism in 2009 with the emergence of terrorist group known as Boko Haram in the Northern part of the country. Due to the activities of Boko Haram which included killing, arson, attacks on police and army, bombing, shooting, abduction and kidnapping etc drawn the attention of Nigerian government and the International Community towards curbing the menace of terrorism in the country. Boko Haram which literarily translates into 'western education is forbidden' has an ideology that is based on a fundamentalist Sunni Islam, and their intent is to establish an Islamic state in Nigeria and cleanse the country of any and all Western influence (Uzochukwu, M; 2014). This work focuses on terrorism and insecurity in Nigeria, the interplay of political economy and terrorism, various factors hindering the counter measures to succeed, conclusion and recommendation.

\section{Contextual Perspective of Political Economy and Counter Terrorism}

For better understanding, it is good to contextualise this work. The Political economy we are looking at in this paper is the economic considerations, gains, motive of terrorism which are playing substantial roles in elongating the war against the insurgents in Nigeria. The economic factors are the unseen variables within and outside Nigeria exacerbating the terror war and making the Nigerian Counter-Terrorism measures difficult to produce the desired results. It has become increasingly impossible for the Federal Government to win the war against insurgency due to the fact that powerful people in the society are said to be sponsoring the terrorists. It has also been widely reported that the Nigerian Army are not well equipped to face the well-armed terrorists. Report had it that Helicopters have been seen in the North East dropping weapons to the Insurgents while the Nigerian Army fighting the terrorists are found using inferior weapons despite trillions of Nigerian Naira claimed to have been spent on buying weapons to fight the insurgency in the country. Gun business has become very lucrative to conflict entrepreneurs as there are unfetter access to procure weapons by the Insurgents and their backers. Counter-Terrorism on the other hand are measures put in place by the Nigeria Government to win the war against the terrorists carrying out insurgent attacks against the military, Police and civilians alike especially in northern parts of Nigeria. Counter-Insurgency is a holistic approach involving both kinetic and soft approaches to deal with terrorism in Nigeria. Unfortunately, the counter terrorism measures have failed to end insurgent war in the country due to the interplay of the political economy and terrorism in Nigeria.

\section{Theoretical Framework}

The theoretical discuss applied in this work is structural theory in the context of terrorism and insurgency. Applying structural theory to the context of terrorism and insurgency, Barkan and Snowden observed that:

Structural theories of revolution emphasize that weaknesses in state structures encourage the potential for revolution.... According to this view, a government beset by problems such as economic and military crises is 
vulnerable to challenges by insurgent forces. Other governments run into trouble when their...policies alienate and even anger elites within the society (Barkan\& Snowden; 1986).

Stressing further on the theory, Barkan and Snowden (1986) argues that the state is the key actor in structural theories of revolution. Its status is the precipitating factor for popular revolutions. Popular discontent, the alienation of elites, and a pervasive crisis are the central ingredients for bringing a society to the brink of revolution. The structural theory assumption is that behaviour and structure are intertwined. In this case, people go through a socialization process and become dependence of the existing social structures, but at the same time social structures are being altered by their activities. This means that social structures are the medium of human activities as well as the result of those activities (Giddens, 1984). However, for the purpose of this study, theory of relative deprivation would be adopted. Relative deprivation theory holds that 'feelings of deprivation and frustration underlie individual decisions to engage in collective action' (Grenshaw, 1981). The central idea of relative deprivation theory suggests that individuals or groups feel deprived when their current circumstances are negatively compared to the situation of others. In sociology, relative deprivation theory is a view of social change and movements according to which people take action for social change in order to acquire something (for example, opportunities, status and wealth) that others possess and which they believe they should have, too. This condition can engender political violence. One observation that must be made about relative deprivation theory is that it has become a popular theory among experts. However, scholars have questioned the link between relative deprivation and social movements. According to Morrison (1971), much of evidence linking social movements to feelings of relative deprivation is indirect. While absolute deprivation clearly leads to feelings of discontent and ultimately efforts to effect social change, feelings of relative deprivation may or may not definitely lead to the creation of social movement and collective identity (Morrison, D. 1971). Another limitation of relative deprivation theory is that it does not focus on the individual. Critics assert that sociologists using relative deprivation tend to examine individual and collective relative deprivation but ignore self-references (Singer, M. 1992).

\section{Terrorism and Insecurity in Nigeria}

Terrorism and insurgency in Nigeria started with an Islamist fundamentalist, Boko Haram who regarded western education as forbidden. The first attack of Boko Haram came in September 2010 in the Northern part of the country where many lives were lost and properties worth millions were damaged. Bard (2005) stressed that insurgency unleashed a wave of violence in northern Nigeria, mostly targeted against government personnel and security officers, Muslim politicians and traditional Muslim religious leaders, and Christians (Bard, E.0. 2005). Boko Haram was inaugurated in 2002 by the cleric Mohammed Yusuf in the city of Maiduguri. He established a mosque and school in order to preach Wahhibism, an ultra-conservative form of Islam. Yusuf's school quickly became radicalised as a jihadi recruitment camp and is rumoured to have received a portion of the $\$ 1.8 \mathrm{~m}(£ 1.3 \mathrm{~m})$ Osama bin Laden'sal-Qaeda distributed in West Africa to bankroll Islamist terror in the aftermath of 11 September attack of America (www.msn.com: 2018). The Islamist insurgents seek to overthrow Nigeria's political establishment and found an Islamic state under strict Sharia law in Nigeria, have her base in Borno and others parts of the north east states of Yobe, Adamawa, Bauchi, Gombe, and Taraba. The terrorists have sparked a humanitarian crisis in the country, leaving more than 20,000 people dead and displacing a further two million through a sustained campaign of domestic terror, attacking government buildings, military bases and schools (www.msn.com: 2018). Yusuf was succeeded by his ruthless deputy AbubakarShekau and, over the next five years, the group continued to conduct a reign of terror, with gunmen on motorbikes carrying out drive-by assassinations on policemen, politicians or clergymen who dared to speak out against them. The Group employed consistent and sustained attacks in which United Nations Compound in Abuja was car bombed on 26 August 2011. 23 died and 75 were injured during the attack. Another incident bomb attack was on villages, markets, bus depots and prisons and the kidnapping of a French family of seven on holiday at a national park across the border in Cameroon on 19 February 2013 (www.msn.com: 2018). Other atrocities carried out by the group include the use of child captives as suicide bombers, typically under the influence of drugs. The Group also engaged in hostage taking in which ransoms were paid and this provided income for Boko Haram. The Militants also sold captive women and children as slaves on Africa's black market. Boko Haram raided a girl's boarding school in Chibok on 14 April 2014, taking 276 of the residents' captive and this provoked outcry around the world especially when Shekau said 'I abducted your girls. I will sell them in the market, by Allah... there is a market for selling humans. Allah says I should sell. He commands me to sell. I will sell women. I sell women,' (www.msn.com: 2018). In August 2014, Shekau appeared in a propaganda video flanked by masked gunmen to declare: 'We are in an Islamic caliphate. We have nothing to do with Nigeria. We don't believe in this name.' The following March, he pledged Boko Haram's support for ISIS, apparently turning his back on al-Qaeda, an organisation of whom his spokesman had said in 2011: that 'They are our elder brothers. We enjoy financial and technical support from them. Anything we want from them we ask them.' (www.msn.com: 2018). Boko Haram has been well supplied with cash and weapons from its earliest days, its men armed with AK-47s and rocket-propelled grenade launchers thanks to funds received from other terror groups, ransoms, the sale of slaves and black-market ivory obtained through poaching and from regional bank robberies. The activities of terrorists in the North East have given impetus to insecurity in other parts of Nigeria such as kidnapping, cattle rustling, banditry and incessant attacks and killings of innocent Nigerians.

\section{Political Economy of Terrorism and Counter Terrorism Measures of Nigeria}

Political economy of terrorism essentially is the interplay of politics and economic dynamics in understanding of prevailing political and economic processes in the fight against terrorism in Nigeria. On the other hand, Counter-terrorism measures/strategy is a government's plan to use the instruments of national power to neutralize terrorists, their organizations, and their networks in order to render them incapable of using violence to instil fear and to coerce the 
government or its citizens to react in accordance with the terrorists' goals. These measures includethe Office of the National Security Advisor, whom is saddled with the responsibility of coordinating all security and enforcement agencies; the Nigerian military has primary responsibility for combating terrorism in the Northeast; while several government agencies also perform counterterrorism functions. This includes the Nigerian Police Force (NPF), Nigeria Security and Civil Defense Corps (NSCDC), and the Ministry of Justice. The NPF has a Counterterrorism Unit and a Terrorist Investigation Branch. Both units are responsible for investigating acts of terrorism and conducting proactive measures to prevent terrorist attacks. In addition to this, due to their knowledge of the local context, community-based security groups, often collectively referred to as the Civilian Joint Task Force, provided critical and necessary responses to the terrorism threat in the Northeast. Unfortunately, these measures have not been able to provide the desired result on countering insurgency in Nigeria due to corruption in the military and regional conspiracy or international politics at play.

\subsection{External funding of Boko Haram}

External funding has made counter-insurgency measures of Nigerian government ineffective. For instance, in May 2013, security agencies in Nigeria discovered an arms warehouse at the residence of a Lebanese national in Kano State. The cache of weapons was located in an underground bunker beneath the master bedroom and investigations point towards the existence of a Hezbollah terrorist cell in Nigeria with links to Boko Haram (www.saharareoters.com; 2013). Some of the weapons confiscated included rocket propelled guns and anti-personnel mines, which were clearly beyond the range of weapons normally stolen by Boko Haram from local police stations (www.saharareoters.com; 2013). In addition to allegations of financial proceeds from local politicians, businessmen and organised criminal networks, suspicions have increased with regard to Boko Haram's interception of charity funds generated by the UK-based aid organisation AlMuntada Al-Islami Trust. In 2012, Lord Alton of Liverpool raised fears in the British parliament about Boko Haram's alleged links with this organisation (www.guardian.co.uk). While the exact context of financial flow from this organisation remains unclear, it calls to mind previous claims about this organisation's involvement in financing a violent uprising in Yobe State, Nigeria in 2003. In relation to this, the director of the charity was arrested by the Nigerian authorities in February 2004 following the discovery of his financial transactions running into millions of Naira with a Kano-based businessman who acted as a middleman between the charity and Boko Haram (Bello, A. 2013). In September 2011, rare pointers regarding Boko Haram's funding sources were further disclosed during a visit led by former Nigerian president Olusegun Obasanjo and civil rights activist Mallam Shehu Sani to the relatives of the late Boko Haram leader, Mohammed Yusuf. On this occasion, Yusuf's family revealed that about $40 \%$ of the group's funding came from outside Nigeria (www.aljazeera.com). They further noted that while the group had representatives in Chad, Niger and Cameroon, it would be difficult for the Nigerian army to crush Boko Haram because of their capacity to reach out beyond Nigeria if they so desired. These statements match some accounts which explain how suicide bombers of the group are usually Chadians, Nigeriens and Cameroonians (Alli, Y. 2012)

\subsection{Corruption in the Military}

Recent reports revealed that some governors are fuelling insecurity in their states in order to justify or even increase their security votes. This secrete was divulged by the Chairman of the Economic and Financial Crimes Commission (EFCC), Mr. Ibrahim Magu, on 1 May 2019 in which he said some of the governors 'now covertly promote insecurity as justification to inflate their security votes (www.punchng.com ).Magu added that 'we have also seen evidence of theft of public resources by some state governors-cashing in on the insecurity in their states (www.punchng.com). It generally believes that the state of insecurity in the country is serving the interest of security agencies including the military as they have converted insecurity into a gold mine. Trillions of Nigerian naira have been spent in the fight against insurgency and general insecurity in Nigeria; while little achievements recorded as security challenges are on the increase. Money meant for counter-insurgency have been diverted by top military brass for their personal use. The $\$ 2.1$ billion 'Dasukigate' of 2015, in which many high-ranking military officers including the former Chief of Army Staff, Alex Bade, was found culpable in the corruption scandal; was a disappointment to the citizenries. Another military corruption scandal in fighting insecurity \& terrorism in Nigeria was recorded when Nigerian Army probed its former General Officer Commanding of the 8 Division, Sokoto State, Maj. General Hakeem Otiki, following the 400million naira said to have been stolen by escort soldiers carrying the money from Sokoto to Kaduna (JideOjo; 2019). The General reportedly asked the soldiers to escort the money and deliver it to a very important personality in Kaduna. The soldiers decided to help themselves by stolen the money as they deserted the army. Unconfirmed report also had it that the commander of theatre of war in the fight against the insurgents has become a very juicy appointment as any appointed commander suddenly becomes a multi-millionaire. Defence Contractors also contribute to corruption in the Military. Military hardware, rations and other equipment needed for the fight against terrorists in the North East are being contracted out to vendors in which most times, contracts are awarded to companies owned by the military top brass inflate contract values. Themultimilliondollar contracts being awarded to the companies of the top military echelons will not want the fight against insurgency come to an end.

\subsection{RegionalConspiracy/International Politics}

Cameroon serves as a recruiting ground for BokoHaram, with the group recently enrolling young Cameroonians from the Kanuri community. The government there now acknowledges that this infiltration has taken place (www.jeuneafrique.com). About 200 youngsters, aged from fifteen to nineteen, have been recruited since February 2014 alone, and are currently training in Nigeria. While most are drawn by financial considerations, others have been forced to enrol for fear of being killed (www.jeuneafrique.com). Allegations of a very lenient policy towards Boko Haram have been 
made against thegovernment,with kidnapping of foreign citizens occurring with little retaliation. One news report even claimed that North Cameroon officials profited financially from ransom paid to release two kidnapped French citizens (www.leseptentrion.net). In light of this, Cameroon has been viewed as the'weakest link', with Nigeria's head of counterterrorismcomplaining on 30 May 2014 that its neighbour wasnot doing enough to fight off Boko Haram (www.reuters.com). For example, Cameroon has not agreed to let Nigerian troops pursue Boko Haram onto its territory, which makes it much easier for jihadists to escape and regroup in a safe haven (www. allafrica.com). Cameroon is also a conduit for its weapons supply. Nigerian jihadists receive weapons through smuggling routes that go from Sudan, Chad, the Central African Republic and finally transiting through north Cameroon (www. allafrica.com) It was reported recently that France is sponsoring Boko Haram. Cameroon is an ally of France and its attitude towards the fight against Boko Haram might have been dictated by France as part of international politics.

\subsection{NGOs and Humanitarian Aids in the North East}

The humanitarian crisis in north east no doubt requires urgent humanitarian interventions in which about two million people have been displaced and thousands of lives have been lost. The United Nations Office for the Coordination of Humanitarian Affairs (UNOCHA), noted that about US\$1.6 billion would be required to ease hunger, provide shelter and healthcare and help communities rebuild their livelihoods (www.reliefweb.int; 2019). This explains why too many NGOs and Humanitarian Organizations dotted the region in a bid to help address these problems created by insurgency in the region. However, the conducts of these NGOs have come under scrutiny and their numbers have raise suspicion. By 2018, Maiduguri hosted at least 150 non-governmental organisations (NGOs) involved in humanitarian work in which some of them were challenged by state authorities over accountability issues. In addition to government's allegation of accountability; a group known as Concerned Professionals Congress (CPC), has also accused unnamed international nongovernmental organisations (NGOs) of making 10 years upfront payment for hotel accommodation in Maiduguri, the Borno State capital (www.thisdaylive.com; 2018). The group said 10 years upfront payment for hotel accommodation was an indication that some of the organisations were working for forces bent on ensuring that the war never ends. It alleged that several NGOs being sustained by international donors also complicate matters like Amnesty International who 'They make false human rights abuse claims in order to demoralise and frustrate our troops from making headway. They don't want the war to end so they don't condemn Boko Haram,' (www.thisdaylive.com; 2018). The shutdown of some NGOs' offices by the Nigerian Army may be unconnected to the activities of the NGOs in the region. In the early part of September 2019, the Army short down regional offices of two prominent NGOs operating in the country's north east amid a brutal insurgency led by Boko Haram. First, it sealed the offices of Action Against Hunger, the global non-profit focused on providing food aid. It accused the International body of supporting terrorists (www.qz.com;2019). The Maiduguri office was sealed up on the $19^{\text {th }}$ September 2019. That was followed by the closure of four (4) offices of Mercy Corps, another prominent non-profit international body in the troubled north east region. In response, Mercy Corps has suspended its operations in parts of the region. The organization suspended its operations in Borno, and Yobe States, Nigeria, following the closure of four of the field offices by the Nigerian Military (af.reuters.com; 2019). International NGOs are largely suspected to be aiding and abetting terrorist groups in the North East of Nigeria. Many NGOs and CSOs have shifted their focus for economic considerations. It is common to see many non-profit organizations shifting their agenda and engaging in other things for financial gains.

\subsection{Kidnapping \& Hostage Taking For Ransom Payment}

Boko Haram engaged in kidnapping of people for ransom as well as young boys to replenish their folds as fighters. On 14 April 2014, at least 276 girls were taken from a Government Secondary School in Chibok town, Borno State, by Boko Haram. On the evening of February 19, 2018, at 5;30 pm local time, militants dressed in army fatigues stormed a School, kidnapped 110 schoolgirls aged 11-19 years old from the Government Girls Science and Technical College (GGSTC), Dapchi, BulabulinYunusari Local Government Area, Yobe State, North East Nigeria. Over the years, as part of a deal between the Nigerian Government and the armed gang; a number of kidnapped girls have been released. According to Government Officials, at least 104 of the 110 girls who had been kidnapped in Dapchi had been returned. For the girls kidnapped in Chibok, in October 2016, the first mass of girls released were 21 girls following negotiation between government and Boko Haram, brokered by the International Christian Red Cross, ICRC (bbc.com; 2017). It is believed that Boko Haram Prisoners were freed in exchange. Then in May 2017, another 82 girls were freed, once again with the help of ICRC (bbc.com; 2017). This leaves 113 girls who are still unaccounted for. It is believed that they are still being held by Boko Haram, although there are reports that some may have died. It was generally believed that the release of some of these girls did not just happen without ransom being paid by the government. Those that have not been released have been married off, used as sex slaves, as human bombs, brainwashed and radicalised. In May 2016, an army-backed Vigilante Group in Zambisa Forest, a Boko Haram stronghold close to the border with Cameroon; found one of the girls with a child (bbc.com; 2017). Beyond hatred of Boko Haram against western education, economic motives may have also driven the group's abduction of the Chibok school girls. Boko Haram leader, Shekahu, boasted that he would sell the captured girls as slave market exists in Nigeria and neighbouring countries. The US military academy, said: 'Kidnapping has become one of [Boko Haram's] primary funding sources, a way to extract concessions from the Nigerian state and other governments, and a threat to foreigners and Nigerian government officials.' Experts now estimate that kidnapping is worth 'millions of dollars in ransom money' to the militants (www.nairametrics.com;2015) 


\subsection{Illicit Trading}

Boko Haram have been engaging in illicit trade to sustain their insurgent attacks in the north east. Cattle rustling is a criminal act which Boko Haram have deployed and proceeds from stealing peoples' cows have been largely used to sustain the group's operation in the region. Illicit trading in small arms by the Boko Haram is a source of fund for Boko Haram. This is made possible due to the porous nature of the Nigerian borders. The recent disclosure by Nigeria's former Minister of Interior, Abba Moro, that there are over 1,499 irregular (illegal) and 84 regulars (legal) officially identified entry routes into Nigeria, confirms the very porous state of these borders which permits illicit transnational arms trafficking. In Adamawa State, there are about 25 illegal routes into Nigeria from neighbouring countries. Terrorists and smugglers take advantage of this leakage to smuggle small arms and light weapons (SALWs) into Nigeria. As a result, over 70 percent of about 8 million illegal weapons in West Africa was reported to be in Nigeria (www.studies.aljazeera.net). Boko Haram has been able to smuggle arms into Nigeria using various methods such as the use of specially crafted skin or thatched bags attached to camels, donkeys and cows where arms are concealed and moved across the borders with the aid of nomadic pastoralists or herders. Its members are known to connive with merchants involved in cross-border trade to help stuff their arms and weapons in goods that are transported via heavy trucks, trailers, and Lorries. Given the huge size of the goods loaded on these vehicles, very little or no scrutiny is conducted on them by security and border officials (Musa, S; 2013). This is made possible through the complicity of transnational actors which serves as a threat to Nigeria's national security and economic interests. Bank robberies and extortions of the locals is another way political economy of terrorism plays out. Many banks were robbed in which the terrorists broke into many banks through the use of dynamite. This author personally saw a bank in Wukari, TarabaState, that was bombed by the terrorist in 2012. Boko Haram has partly financed its militant operations by attacking and robbing banks. The group has robbed hundreds of banks in its home province of Borno and two other northern regions of Nigeria. The robbery is justified by Koranic interpretation that bank robbery is permitted, since the money from the banks is considered 'spoils of war.' Terrorists extort the local population by confiscating their farm produce, visit the local market on market days and loot their goods and food items, implement random taxes at any time to quickly fill depleted coffers. For instance, it was reported that Boko Hara at a time was controlling Baga fish market in Borno State. Through the instrumentality of violence, terrorists do also collect taxes and fees in the areas under their control.

\subsection{Government Officials Sponsoring/Leading the Terrorists}

There have been serious allegations against some officials of government involving in sponsoring or leading BokoHarram terror group in Nigeria. A former Deputy Governor of Central Bank of Nigeria (CBN), Obadiah Mailafia, says he got the information about a Northern Governor leading and sponsoring Boko Haram from some Fulani traders in a market (www.eonsintelligence.com: 2020). Mailafia said this during a radio program in Abuja in August while speaking on the current crisis in Southern Kaduna, his home state. He said he had a chat with two repentant terrorists, who identified the Northern Governor to him. Mailafia said Boko Haram had already infiltrated Southern Nigeria, adding that their plan was to spark a second civil war. He said " some of us also have our intelligence network. I have met with some of the bandits; we have met with some of their high Commanders, one or two who have repented, they have sat down with us not once, not twic"(www.saharareporters.com: 2020). Mailafia stated further " They told us that one of the Northern Governors was the Commander of Boko Haram in Nigeria. Boko Haram and the bandits are one and the same. They have a sophisticated network. During the lockdown, their planes were moving up and down as if there was no lockdown. They were ammunition, moving up and down as if there was no lockdown. They were moving ammunition, moving money, and distributing them across different parts of the country (www.saharareporters.com: 2020). Allegations of government officials belonging to or sponsoring Boko Haram are very loud and disturbing. The former Governor of Borno State, AlimoduSherif, was once accused of sponsoring Boko Haram while in office. He however denied the allegation. A current serving Senator, Ali Ndume, was also once alleged of sponsoring Boko Haram, in which he denied it. The former president of Nigeria, Jonathan Goodluck, when he was in power, spoke out that he had Boko Haram members in his government. The late military dictator in Nigeria, Sanni Abacha, once said for a terrorist to last more than twenty-four hours in a country; it means that that country has a hand in it. This statement is undoubtedly becoming true in the fight against insurgency in Nigeria that has lasted more than ten years. Insurgency in Nigeria has become a big business in which those that are in power and are feeding fat from the insurgency would not want the war against Boko Haram to end for their own economic benefits. The military counter-insurgency plans put in place by the Nigerian government are entrapped by the economic interests of the top notch in government whom are sponsoring or leading Boko Haram terrorists in the country.

\subsection{Illicit Funding}

Boko Haram insurgency has become an avenue for money laundering. Some Nigerians have been convicted in the UAE for funding the notorious terrorist group. Daily Trust local newspaper reported that six Nigerian nationals were convicted by an Abu Dhabi Federal Court of Appeal in the United Arab Emirates (UAE) for funding Boko Haram in 2019. The media platform revealed that the Nigerians were responsible for laundering the sum of \$782, 000 between 2015 and 2016 (www.nairametrics.com; 2020). The report revealed:

'Two of the convicts, SurajoAbubakar Muhammad and Saleh Yusuf Adamu were sentenced to life imprisonment; while the remaining four, Ibrahim Ali Alhassan, AbdurRahman Ado Musa, Bashir Ali Yusuf, and Muhammad Ibrahim Isa were handed ten-year imprisonment respectively,' 'According to the judgment, all the accused were charged with funding a terror group (Boko Haram) by facilitating transfers of money from Dubai to Nigeria for alleged terror operations (www.nairametrics.com; 2020). Also revealed were that Boko Haram uses undercover agents to facilitate its funding, the agents are based in Nigeria. The report stated further: 
'One of them, AlhajiSa'idu, who is allegedly based in Nigeria and said to be a senior undercover Boko Haram member responsible for facilitating the group's access to funds from its sponsors' 'Also fingered in some of the transitions is one AlhajiAshiru, said to be a Nigerian government official and a senior undercover Boko Haram member, who facilitated the transfer of misappropriated public funds to the group." (www.nairametrics.com; 2020).

It is important to know that secret financing of Boko Haram has been reported long before the arrest and sentence of these criminals in UAE. For instance, in 2016, Nairametrics, an online media, reported that Boko Haram started a form of microfinance by providing or promising capital and loans to young entrepreneurs and business owners in northeast Nigeria, as a ploy to get them to join the group; Mercy Corps, an Aid Corps reported that Boko Haram was exploiting the poverty facing most small business owners from butchers and beauticians to tailors and traders, to get them to accept the loans in exchange for joining Boko Haram, and in 2015, a survey of academic, governmental and journalistic accounts, reported that Boko Haram funds its escalating acts of terror through black market dealings, local and international benefactors, and links to al-Qaeda and other well-funded groups in the Middle East, such as ISIS. Despite all these reports, the Nigerian government failed to any meaning action to counter Boko Haram illicit funding as it is often said, funding is the blood of terrorists and once it's stopped, terrorism will stop. The reports from the UAE have shown that terrorist groups work with some government agencies to hide from suspicion. The report also revealed Boko Haram has their money laundered through Bureau de Changes. One must admit that tracing terrorism funding is a problem globally and also a problem in Nigeria; it is however expected of the government to take a proactive measure to curb illicit financing of Boko Haram in the country.

\section{Conclusion and Recommendations}

Given the complexities of the Boko Haram threat, a comprehensive approach is needed to effectively counter the group. This goes beyond hard-line or military responses that the government has been using to address the issue in the North East. A comprehensive approach necessarily needs to be built on a deep understanding of the drivers and dynamics of the North East; military measures and security cooperation with neighbouring states, such a counter-terrorism approach needs to be sought as well as inter-religious dialogues and mediation processes. The counter-insurgency measures should also seek to address issues of socio-economic development and governance, as well as the problem of prosecuting, detaining and rehabilitating Boko Haram militants who have broken the law. The government should equally collaborate with external and non-governmental actors on all levels for the success of counter-insurgence measures put in place. Boko Haram has a wide variety of outlets for its fundraising activity and Its success in sustaining attacks depends on a well-oiled financial pipeline. The Group collaborates with organized crime syndicates for its operations in drug trafficking, kidnappings, bank robbery, and cyber scams, not to mention continuous theft from Nigeria's security establishment. The apex bank, CBN, should put in place tighter currency transfer regulations and demands for more transparency into dealings and the sources of funds.

\section{References}

i. Al Jazeera, 'Suspects charged in Nigeria bombing' (25 December 2011), http://www.aljazeera.com/news/africa/2011/09/201191741850730889.html.

ii. Alli, Y. (2012), 'How bombers are chosen, by Boko Haram suspect', http://www.thenationonlineng.net/2011/index.php/news/36248-how-bombers-are-chosen-by-bokoharam-suspect.html. Obtained November 2019

iii. Barkan\& Snowden, (1986). 'Collective violence.' In J.A. Goldstone (ed.) Introduction: The comparative and historical study of revolutions. San Diego: Harcourt Brace Jovanovich. 1-17

iv. Bard, E.0. (2005). Insurgency and terrorism: From revolution to apocalypse. Potomac Books, Inc. pp. 19-29

v. Bello, A. (2013), 'Boko Haram: The Greatest Security Threat to the Sovereignty of Nigeria' (2013), p. 70.

vi. Cameroun - Nigeria: Boko Haram, la menace fantôme', JeuneAfrique, 1 May 2013

vii. Doward, J. (2012), 'Peer raises fears over UK charity's alleged links to Boko Haram', http://www.guardian.co.uk/world/2012/sep/09/uk-charity-boko-haram.Obtained November 2019.

viii. Giddens, A. (1984). The consequences of modernity. Stanford University Press.

ix. Grenshaw, M. (1981). 'The causes of terrorism' In D.J. Whittaker (ed.) The Terrorism Reader. New York: Routledge pp. 19-20. Gurr

x. JideOjo; (2019), The Political Economy of Insecurity in Nigeria, In, Readings in Peace \& Conflict; Essays in honour of Professor Isaac Olawale Albert. Pg.78-82.

xi. Morrison, D. (1971). Some notes toward theory on relative deprivation and social movements. The American Behavioural Scientist. 14(5), 675

xii. Musa, S. (2013), 'Border Security, Arms Proliferation and Terrorism in Nigeria,' Sahara Reporters, 20 April, http://saharareporters.com/article/border-security-arms-proliferation-and-terrorism-nigeria-lt-colsagir-musa?goback=.gde_4451300_member_234179302.

xiii. Singer, M. (1992). The application of relative deprivation theory to justice perception of preferential selection. Current Psychology, 11(2), 128-145.

xiv. Uzochukwu, M. (2014). Challenges in Nigeria and solutions on how to resolve them. Politics and Social Issues,22(4), 122-135

xv. www. msn.com: 2018. Obtained November 2019

xvi. www.saharareporters.com: 2013. Obtained November 2019. 'Nigerian Army Links Boko Haram to Hezbollah' (30 May 2013), 
xvii. www.saharareporters.com: 2013. Obtained November 2019. Such incidents include the raid on police stations in Bama and Gwoza areas of Borno State in September 2004.

xviii. www.punchng.com). Obtained 5 November 2019

xix. www.jeuneafrique.com. Cameroun, Tchad, Niger, Bénin: ces pay sous la menace de Boko Haram', JeuneAfrique, 15 May 2014. Article/ARTJAWEB20140514174552/. Obtained 7 December 2019

xx. www.jeuneafrique.com. 'Cameron: Boko Haram recrute des jeunes à la frontiére avec leNigeria', JeuneAfrique, 3 April 2014, Article/ARTJAWEB20140403115835/cameroun-terrorisme-boko-haram-nigeriacamerounboko-haram-recrute-des-jeunes-a-la-frontiere-avec-le-nigeria. Html. Obtained 7December 2019

xxi. www.leseptentrion.net. Boko Haram infiltrel 'administrationcamerounaise', La Septentrion, /2014/05/bokoharam-infiltre-ladministration-camerounaise. Obtained 7 December 2019

xxii. www.reuters.com. 'Cameroon weakest link in fight against Boko Haram: Nigeria',

xxiii. Reuters, 30 May 2014, available at

http: article/2014/05/30/us-nigeria-boko-haram-idUSKBN0EA1LE20140530. Obtained 7 December 2019

xxiv. www.allafrica.com. Jonathan - Our Soldiers Can't Pursue Boko Haram to Cameroon', All Africa, 18 May 2014 , stories/201405190454. Html. Obtained 7 December 2019

xxv. www.reliefweb.int/report/nigeria/humanitarian-aid-nigeria-s-north-east-helping-or-hurting. Obtained 20 June 2020

xxvi. www.thisdaylive.com/index.php/2018/10/08/insurgency-group-accuses-ngos-of-paying-upfront-10-yearshotel-accommodation-in-maiduguri/amp/. Obtained 20 June 2020

xxvii. www.qz.com;2019. Obtained 12 June 2020

xxviii. www.af.reuters.com. Obtained 12 June 2020

xxix. www.bbc.com. Obtained 12 June 2020

xxx. www.studies.aljazeera.net/en/reports/2013/09/201398104245877469.html. Obtained 20 October 2020

xxxi. www.eonsintelligence.com. Obtained 3 November 2020

xxxii. www.saharareporters.com. Obtained 3 November 2020

xxxiii. www.nairametrics.com. Obtained November 2020. 